\title{
BIOREMEDIASI LOGAM TIMBAL (Pb) DALAM TANAH TERKONTAMINASI LIMBAH SLUDGE INDUSTRI KERTAS PROSES DEINKING
}

\author{
Henggar Hardiani ${ }^{\text {* }}$, Teddy Kardiansyah ${ }^{\text {a }}$, Susi Sugesty ${ }^{\text {a }}$ \\ ${ }^{a}$ Balai Besar Pulp dan Kertas \\ Jl. Raya Dayeuhkolot 132 Bandung 40258 Telp. (022) 5202980 Fax. (022) 5202871 \\ * e-mail : henggarh@yahoo.co.uk \\ Diterima : 2 Maret 2011, Revisi akhir : 6 Juni 2011

\begin{abstract}
BIOREMEDIATION OF SOIL CONTAMINATED HEAVY METAL PB FROM DEINKING PROCESS SLUDGE WASTE IN THE PAPER INDUSTRIES
\end{abstract}

\begin{abstract}
Sludge waste of deinking process as toxic and hazardous material from spesific source containing $\mathrm{Pb}$ metal from waste water soluble ink. According to regulation of Ministry of Environmental no.33/2009 that all the industries are mandatory to clean up contaminated soil from hazardous waste. Therefore this bioremediation research need to be conducted using consortium microbes. This research was conducted by applying variation of incubation $0-60$ days and inoculum $5 \%, 10 \%$ and $15 \%(v / w)$. Key success parameter of bioremediation is transformation of metal from active to inactive phase in contaminated soil by microbial activity stated by deceases of soluble-exchangeable $\mathrm{Pb}$ and increases of residual $\mathrm{Pb}$. The 1:1:1:1 consortium microbes of PG 65-06 (A) : PG 97-02 (B) : MR 1.12-05 (C) : A1 (D) reached an optimum condition with $10 \%$ inoculum and 40 days incubation indicated by decrease of coefficient distribution until $21 \%$ in soluble-exchangeable Pb from initial 19,36 mg/kg to $15,91 \mathrm{mg} / \mathrm{kg}$ and increase of coefficient distribution until $146 \%$ in residual Pb from initial 7,77 mg/kg to 17,00 mg/kg. Germination index value $84,3-136,7 \%$ means contaminated soil is not toxic to plants.
\end{abstract}

Key words : bioremediation, soil contaminated, deinking waste paper industries, heavy metal Pb

\begin{abstract}
ABSTRAK
Limbah sludge proses deinking sebagai $\mathrm{B} 3$ dari sumber spesifik karena mengandung logam $\mathrm{Pb}$ dari tinta yang larut dalam air limbah. Menurut Kep.Men. LH no. 33/2009 semua industri wajib melakukan pemulihan lahan tekontaminasi limbah B3. Oleh karena itu perlu dilakuan penelitian bioremediasi menggunakan mikroba konsorsium. Penelitian dilakukan dengan variasi waktu inkubasi dari $0-60$ hari dan jumlah inokulum $5 \%, 10 \%$, dan $15 \%$ (v/w). Keberhasilan bioremediasi adalah mengubah logam aktif dalam tanah menjadi tidak aktif oleh aktifitas mikroba, dinyatakan dengan penurunan nilai koefisien distribusi fase tertukarkan dan peningkaan fase residual Pb. Mikroba konsorsium PG 65-06 (A) : PG 97-02 (B) : MR 1.12-05 (C) : A1 (D) dengan perbandingan 1:1:1:1 menghasilkan kondisi optimum untuk penambahan inokulum 10\% dan waktu inkubasi 40 hari dengan penurunan koefisien distribusi fase tertukarkan $\mathrm{Pb}$ sebesar 21\% yang semula $19,3 \mathrm{mg} / \mathrm{kg}$ menjadi $15,91 \mathrm{mg} / \mathrm{kg}$ dan peningkatan fase residual $\mathrm{Pb}$ sebesar $146 \%$ yang semula $7,77 \mathrm{mg} / \mathrm{kg}$ menjadi $17,00 \mathrm{mg} / \mathrm{kg}$. Nilai germination index pada kisaran $84,3-136,7 \%$ yang berarti tanah tersebut sudah tidak bersifat toksik pada tanaman.
\end{abstract}

Kata kunci : bioremediasi, tanah terkontaminasi, limbah deinking industri kertas, logam berat $\mathrm{Pb}$ 


\section{PENDAHULUAN}

Industri Kertas dengan proses deinking adalah salah satu industri yang menghasilkan limbah padat yang diklasifikasikan sebagai limbah B3 dari sumber yang spesifik (Peraturan Pemerintah No18/1999 dan 85/1999 tentang Pengelolaan Bahan Berbahaya dan Beracun). Pada umumnya limbah padat tersebut mengandung logam $\mathrm{Pb}, \mathrm{Cr}$, $\mathrm{Cu}, \mathrm{Ni}, \mathrm{Zn}, \mathrm{Cd}$ dan $\mathrm{Hg}$ yang berasal dari tinta yang larut dalam air limbah (Gottsching et. al, 2000). Masalah yang seringkali muncul pada saat ini adalah tercemarnya tanah oleh bahan berbahaya dan beracun (B3). Tanah terkontaminasi limbah proses deinking mengandung logam berat $\mathrm{Cd}$ sebesar 2,30 mg/kg; $\mathrm{Ni}: 16,2$ dan $\mathrm{Pb}: 22 \mathrm{mg} /$ kg (Hardiani, 2008) cukup tinggi dibandingkan dengan persyaratan logam dalam tanah tidak berbahaya (Cd 0,08 dan Ni 0,4 mg/kg), sedangkan untuk $\mathrm{Pb}$ sebesar $20 \mathrm{mg} / \mathrm{kg}$ (Alloway, 1995). Mengacu kepada karakteristik tersebut bahwa kandungan logam $\mathrm{Pb}$ cukup besar dibandingkan dengan logam lainnya, maka penelitian dititik beratkan pada $\mathrm{Pb}$. Logam $\mathrm{Pb}$ termasuk logam berat yang dikategori ke dalam bahan berbahaya dan beracun (B3). Jumlah logam $\mathrm{Pb}$ dalam tanah dapat menggambarkan kondisi tanah telah terjadi kontaminasi atau tidak terkontaminasi. Kontaminasi logam berat di lingkungan merupakan masalah, karena akumulasinya sampai pada rantai makanan dan keberadaannya di alam tidak mengalami transformasi (persistent), sehingga menyimpan potensi keracunan yang laten (Notodarmojo, 2005). Keberadaan logam berat dalam tanah perlu mendapatkan perhatian yang serius karena tiga hal, meliputi: 1) bersifat racun dan berpotensi karsinogenik; 2) logam dalam tanah pada umumnya bersifat mobile 3) mempunyai sifat akumulatif dalam tubuh manusia (Notodarmojo, 2005).

Pada tahun 90-an, penanganan dan pengelolaan limbah padat di industri kertas umumnya dibuang secara timbunan terbuka (open dumping) di lokasi sekitar pabrik. Menurut Peraturan Menteri Negara Lingkungan Hidup No. 33 Tahun 2009 (pasal 3) tentang Tata Cara Pemulihan Lahan Terkontaminasi Limbah Bahan Berbahaya dan Beracun menyatakan bahwa penanggungjawab usaha atau kegiatan wajib melakukan pemulihan lahan terkontaminasi limbah bahan berbahaya dan beracun yang diakibatkan dari usaha atau kegiatannya. Oleh karena itu perlu dilaksanakan pemulihan lahan terkontaminasi limbah bahan berbahaya dan beracun. Salah satunya limbah bahan berbahaya dan beracun tersebut adalah timbal $(\mathrm{Pb})$ yang dihasilkan oleh kegiatan industri kertas proses deinking. Logam $\mathrm{Pb}$ merupakan logam berat yang sangat beracun dan tidak dibutuhkan oleh manusia, sehingga bila makanan tercemar oleh logam tersebut, tubuh akan mengeluarkannya. $\mathrm{Di}$ dalam tubuh manusia, logam $\mathrm{Pb}$ bisa menghambat aktivitas enzim yang terlibat dalam pembentukan hemoglobin $(\mathrm{Hb})$ dan sebagian kecil logam $\mathrm{Pb}$ dieksresikan lewat urin atau feses karena sebagian terikat oleh protein, sedangkan sebagian lagi terakumulasi dalam ginjal, hati, kuku, jaringan lemak, dan rambut (Widowati, 2008). Salah satu pilihan untuk mengatasi masalah kontaminasi oleh logam $\mathrm{Pb}$ adalah bioremediasi menggunakan mikroba (Suhendrayatna, 2001). Tindakan remediasi perlu dilakukan agar lahan yang tercemar dapat digunakan kembali untuk berbagai kegiatan secara aman.

Bioremediasi merupakan pengembangan dari bidang bioteknologi lingkungan dengan memanfaatkan proses biologi dalam mengendalikan pencemaran dan cukup menarik. Selain hemat biaya, dapat juga dilakukan secara in situ langsung di tempat dan prosesnya alamiah (Erman, 2006). Laju degradasi mikroba terhadap logam berat tergantung pada beberapa faktor, yaitu aktivitas mikroba, nutrisi, derajat keasaman dan faktor lingkungan (Donlon, 2006). Teknologi bioremediasi ada dua jenis, yaitu ex-situ dan in situ. Ex-situ adalah pengelolaan yang meliputi pemindahan secara fisik bahan-bahan yang terkontaminasi ke suatu lokasi untuk penanganan lebih lanjut (Vidali, 2001). Penggunaan bioreaktor, pengolahan lahan (landfarming), pengkomposan dan beberapa bentuk perlakuan fase padat lainnya adalah contoh dari teknologi ex-situ, sedangkan teknologi in situ adalah perlakuan yang langsung diterapkan pada bahanbahan kontaminan di lokasi tercemar (Vidali, 2001).

Atas dasar uraian tersebut di atas, maka perlu dilakukan penelitian pemulihan lahan terkontaminasi logam $\mathrm{Pb}$ pada lokasi bekas timbunan limbah padat industri kertas proses deinking agar lahan yang tercemar dapat digunakan kembali untuk berbagai kegiatan secara aman. 
Ruang lingkup penelitian ini meliputi karakterisasi media tanah terkontaminasi limbah deinking dan limbah sludge; pembuatan inokulum mikroba dan dilanjutkan dengan percobaan bioremediasi sistem batch. Seluruh kegiatan penelitian dilakukan dalam skala Laboratorium. Keberhasilan bioremediasi adalah dapat mengubah logam aktif dalam tanah terkontaminasi menjadi tidak aktif oleh aktivitas mikroba (Huang, 2005).

Dengan melaksanakan penelitian ini diharapkan agar teknologi bioremediasi yang menggunakan mikroba dapat digunakan sebagai metode pemulihan tanah terkontaminasi logam $\mathrm{Pb}$ dapat dijadikan sebagai alternatif pengembangan teknologi pengolahan limbah ramah lingkungan. Kemampuan mikroba tersebut dapat dijadikan sebagai informasi bagi industri pulp dan kertas untuk memecahkan permasalahan pemulihan pembuangan limbah padat yang mengandung logam $\mathrm{Pb}$.

\section{BAHAN DAN METODE}

\section{Bahan dan Alat}

1. Tanah Percobaan, tanah terkontaminasi diambil dari lahan pembuangan limbah padat pabrik kertas proses deinking umur timbunan 3-5 tahun. Cara pengambilan contoh tanah dilakukan secara acak dengan memetak $2 \mathrm{x}$ $2 \mathrm{~m}$ pada kedalaman sekitar $1 \mathrm{~m}$. Selanjutnya dicampur dan dikeringkan secara alami, diserbuk dan disaring menggunakan saringan nylon $2 \mathrm{~mm}$, serta di inkubasi selama 1 minggu agar tanah yang digunakan relatif stabil (Mamik, 2004).

2. Mikroba yang digunakan adalah mikroba konsorsium, campuran dari beberapa jenis bakteri pengakumulasi logam $\mathrm{Pb}$ yaitu $\mathrm{PG}$ 65-06 (A) : PG 97-02 (B); MR 1.12-05 (C) dan A1 (D) dengan perbandingan 1:1:1:1. Kultur tersebut diperoleh dari Balai Litbang Bioteknologi dan Sumberdaya Genetika Pertanian (Erny, 2003).

3. Reaktor yang digunakan dalam percobaan ini terdiri dari rangkaian reaktor skala laboratorium dengan ukuran tinggi $30 \mathrm{~cm} \mathrm{x}$ diameter $10 \mathrm{~cm}$, yang dilengkapi dengan $\mathrm{CO}_{2}$ removal trap, tabung penangkap $\mathrm{CO}_{2}$.

\section{Metode}

Penelitian dilakukan di laboratorium yang meliputi, karakterisasi media tanah terkontaminasi limbah deinking ; pembuatan inokulum mikroba dan percobaan bioremediasi. Tahapan percobaan dapat dilihat pada diagram alir penelitian Gambar 1.

1. Karakterisasi tanah terkontaminasi limbah deinking dan limbah sludge, meliputi parameter kandungan logam dalam tanah yang meliputi $\mathrm{Cd}, \mathrm{Cr}, \mathrm{Cu}, \mathrm{Pb}, \mathrm{Ni}$ dan $\mathrm{Zn}$. Metode analisa mengacu Standard Methods for the Examination of Water \& Wastewater, APHA, 21 $1^{\text {st }}$ Edition, 2005 diukur dengan Direct Air Acetylene Flame Method, AAS.

2. Pembuatan inokulum mikroba. Mikroba konsorsium yang digunakan dalam penelitian dikultur pada medium Pepton glukosa ekstrak (PGE) cair, diaktivasi 3 kali dengan menggunakan medium yang sama selama 24 jam pada suhu $37^{\circ} \mathrm{C}$ dengan kecepatan pengadukan $150 \mathrm{rpm}$. Setiap inokulum kultur secara terpisah, satu ose biakan di inokulasi ke dalam $10 \mathrm{~mL}$ medium PGE, kemudian diinkubasi 1 hari dan dianalisis jumlah selnya. Inokulan campuran 2,5 $\mathrm{mL}$ dari masing-masing inokulan tunggal diinokulasikan ke dalam 2 liter medium PGE, kemudian diinokulasikan hingga mencapai minimum $10^{9} \mathrm{sel} / \mathrm{mL}$ (Mamik, 2004). Pembuatan inokulum hasil akhirnya adalah inokulum yang siap dipakai untuk kegiatan bioremediasi.

3. Percobaan dilakukan dengan menggunakan tanah terkontaminasi limbah kertas proses deinking. Sebanyak $1,5 \mathrm{~kg}$ tanah kering udara ditimbang dan dimasukkan ke dalam reaktor bioremediasi yang dialiri udara untuk aerasi, kemudian diinokulasi dengan suspensi mikroba campuran dan diaduk secara merata. Pengamatan terhadap kadar air dilakukan setiap 3 hari sekali dan dilakukan pengadukan. Kadar air dijaga sekitar $60 \%$, diatur dengan menambahkan air. Percobaan dilakukan dengan variasi perlakuan jumlah inokulum : kontrol; $5 ; 10$ dan $15 \%(\mathrm{v} / \mathrm{w})$ dan waktu inkubasi : $10 ; 20 ; 30 ; 40 ; 50$; dan 60 hari. Percobaan dilakukan dalam ulangan 3 kali. 


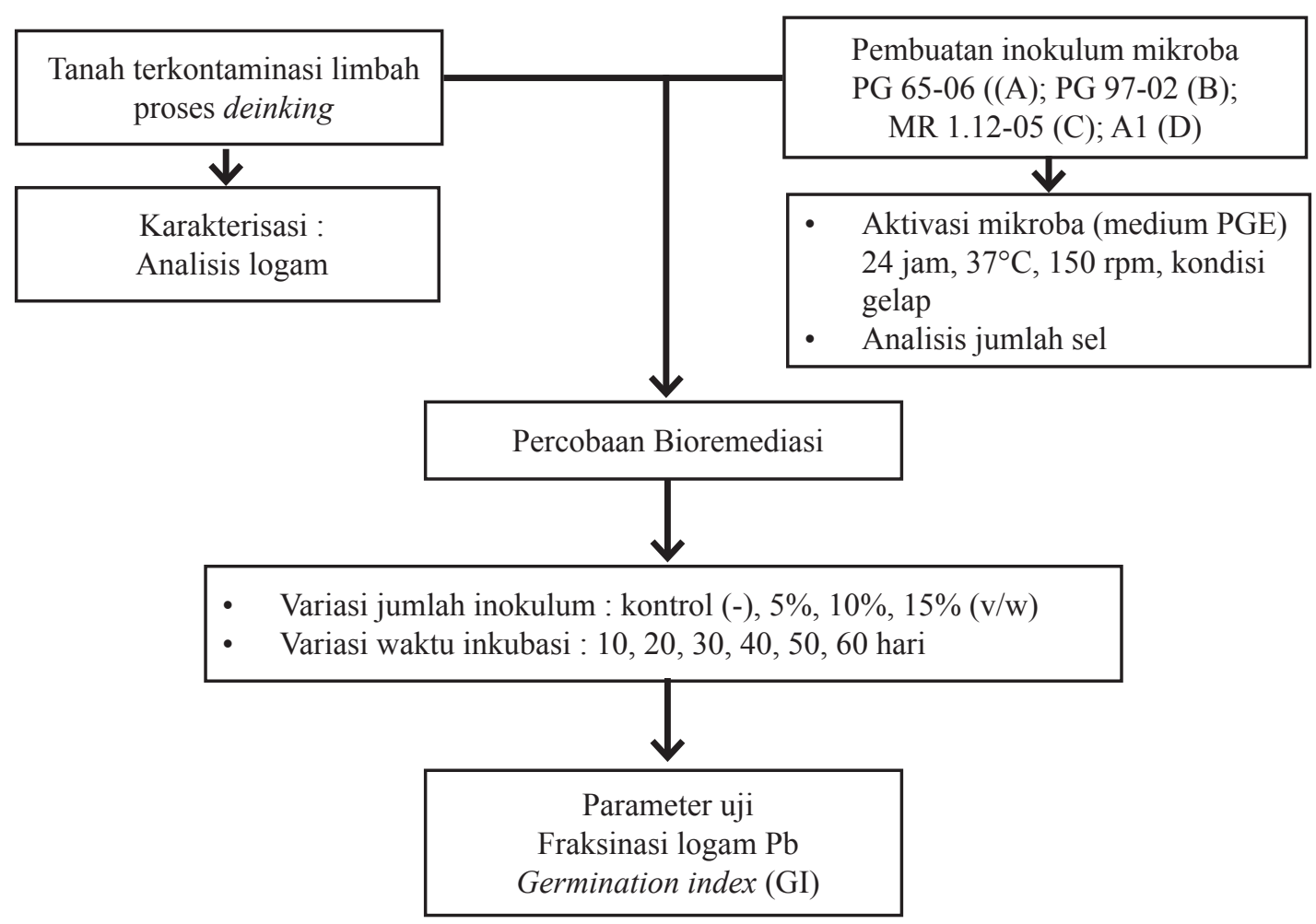

Gambar 1. Diagram Alir Penelitian

4. Pengamatan parameter logam $\mathrm{Pb}$ meliputi : Soluble-exchangeable, Bound to carbonates, Bound to $\mathrm{Fe}-\mathrm{Mn}$ oxides, Bound to organic matter, dan Residual, Prosedur analisis mengikuti Sequential Extraction Procedure (Amanda, 2010). Alat yang digunakan untuk ekstraksi adalah shaker dan sentrifuse.

5. Penentuan Germination index (GI) dengan menggunakan tanaman Brassica oleracea L. dan percobaan dilakukan dalam ulangan 3 kali (Gao et al., 2010).

6. Metode evaluasi data

- Secara statistik dengan ANAVA Uji F

- Perhitungan koefisien distribusi (Huang, 2005)

\section{HASIL DAN PEMBAHASAN}

\section{Karakterisasi Logam Berat}

Secara umum hasil analisis total logam dalam limbah sludge dan tanah terkontaminasi limbah sludge proses deinking menunjukkan bahwa parameter logam $\mathrm{Cd}, \mathrm{Ni}, \mathrm{Cr}, \mathrm{Zn}, \mathrm{Pb}$ dan $\mathrm{Cu}$ cukup tinggi dibandingkan dengan persyaratan logam dalam tanah tidak berbahaya. Hasil analisis tersebut dapat dilihat pada Tabel 1. Konsentrasi logam berat dalam tanah terkontaminasi lebih tinggi dibandingkan dengan limbah sludge, terutama logam $\mathrm{Cu}, \mathrm{Cr}$ dan $\mathrm{Zn}$, sedangkan logam $\mathrm{Pb}$ tidak tersedia data persyaratan menurut AMEG. Nilai tersebut melebihi nilai maksimal tanah tidak berbahaya menurut AMEG, sehingga dianggap berbahaya bagi manusia atau populasi biologis.

Meningkatnya kandungan logam dalam tanah terkontaminasi menunjukkan bahwa logam telah terkonsentrasi dalam tanah. Meningkatnya kandungan logam dalam tanah terkontaminasi ini disebabkan karena tanah terkontaminasi sudah cukup lama sekitar 3 tahun lebih, sehingga senyawa organik yang ada telah mengalami degradasi. Oleh karena itu kandungan logam yang ada dalam tanah terjadi peningkatan. Menurut Notohadiprawiro (2006) menuturkan bahwa batasan kadar beracun beberapa logam terhadap ternak, yaitu untuk logam $\mathrm{Cr}$ (50-3000 mg/kg); Cu (30-100 mg/kg); $\mathrm{Pb}(10-30 \mathrm{mg} / \mathrm{kg})$ dan $\mathrm{Zn}(500 \mathrm{mg} / \mathrm{kg})$.

Dari hasil analisis karakteristik tanah terkontaminasi menunjukkan bahwa logam $\mathrm{Pb}$ sebesar $63,1 \mathrm{mg} / \mathrm{kg}$ dan menurut batasan kadar 
Tabel 1. Hasil Analisis Logam Berat

\begin{tabular}{lccc}
\hline \multirow{2}{*}{ Parameter } & \multicolumn{2}{c}{$\begin{array}{c}\text { Hasil Analisis } \\
(\mathrm{mg} / \mathrm{kg})\end{array}$} & $\begin{array}{c}\text { Nilai maks. dalam } \\
\text { tanah tidak berbahaya }{ }^{1} \\
(\mathrm{mg} / \mathrm{kg})\end{array}$ \\
\cline { 2 - 3 } & Limbah Sludge & Tanah & Terkontaminasi \\
Kadmium $(\mathrm{Cd})$ & 3,8 & 4,9 & 0,08 \\
Khrom $(\mathrm{Cr})$ & 15,1 & 57,8 & 10 \\
Tembaga $(\mathrm{Cu})$ & 110 & 140 & 2,0 \\
Timah $(\mathrm{Pb})$ & 39,0 & 63,1 & $22^{2}$ \\
Nikel $(\mathrm{Ni})$ & 13 & 16 & 0,4 \\
Seng $(\mathrm{Zn})$ & 142 & 234 & 4,0 \\
\hline
\end{tabular}

Sumber : ${ }^{1}$ Menurut AMEG (Ambient Multimedia Environmental Goal), USA dalam Notodarmojo, 2005

2 Alloway, B.J. 1995. Heavy Metals in Soils.

beracun yang masih bisa ditoleransi oleh hewan ternak sebesar 10-30 mg/kg, oleh karena itu perlu adanya remediasi logam $\mathrm{Pb}$ dalam tanah yang terkontaminasi limbah padat proses deinking di industri kertas.

\section{Aktivasi Mikroba}

Jumlah inokulum mikroba yang digunakan dalam percobaan bioremediasi adalah \pm 109 $\mathrm{CFU} / \mathrm{ml}$ (log cell density 9,1). Inokulum tersebut merupakan hasil konsorsium 4 jenis bakteri yaitu PG 65-06 (A), PG 97-02 (B), MP 1.12-05 (C) dan A1 (D) dengan perbandingan 1:1:1:1 (v/v). Jumlah sel dari masing-masing bakteri dan hasil konsorsium dapat dilihat pada Gambar 2.

Inokulum tersebut merupakan hasil konsorsium 4 jenis bakteri yaitu PG 65-06 (A), PG 97-02 (B), MP 1.12-05 (C) dan A1 (D) dengan perbandingan 1:1:1:1 (v/v). Keempat bakteri tersebut digunakan dalam penelitian ini karena diketahui mampu mengakumulasi logam $\mathrm{Pb}$ dalam tubuhnya (Erny et al., 2003). Selama percobaan tidak dilakukan variasi perbandingan bakteri yang digunakan karena hanya ingin mengetahui kemampuan keempat jenis bakteri dalam meremediasi logam $\mathrm{Pb}$.

\section{Pengaruh Penambahan Jumlah Inokulum dan Waktu Inkubasi}

Proses bioremediasi tanah terkontaminasi logam $\mathrm{Pb}$ dari limbah padat industri kertas proses deinking telah menggunakan aktivitas mikroba sebagai sumber energi, sumber karbon atau aseptor elektron untuk metabolisme hidupnya. Masuknya bakteri pada ukuran populasi tertentu terutama bakteri yang adaptif dan resisten terhadap lahan terpolusi, dapat mengikat logam berat karena mikroba memproduksi protein permukaan yang mampu mengikat logam berat.

Keberhasilan bioremediasi adalah mengubah logam aktif dalam tanah terkontaminasi menjadi tidak aktif oleh aktivitas mikroba, dengan melalui analisis fraksinasi dengan cara ekstraksi berurutan. Hal ini ditunjukkan dengan adanya peningkatan kandungan logam dalam fase residual dan menurunnya kandungan logam dalam fase tertukarkan. Analisis fraksinasi dengan cara ekstraksi berurutan digunakan secara tidak langsung untuk mengkaji mobilitas potensial dan ketersediaan logam dalam tanah. Fraksi kation yang teradsobsi pada permukaan logam $\mathrm{Pb}$ di dalam tanah menentukan sifat aktif maupun tidak aktif logam dalam tanah. Tujuan dari bioremediasi tanah terkontaminasi logam $\mathrm{Pb}$ adalah mereduksi logam $\mathrm{Pb}$ aktif dalam tanah menjadi tidak aktif (Huang et al., 2005).

Fraksi kation yang teradsorpsi pada permukaan tanah dapat diklasifikasikan berdasarkan ikatan dengan permukaan partikel tanah yang ditentukan menurut metode ekstraksi berurutan (Sequential Extraction). Dalam metoda ini ada lima fraksi kation yang teradsorpsi atau terikat oleh partikel tanah, yaitu dalam bentuk tertukarkan (Exchangeable); 


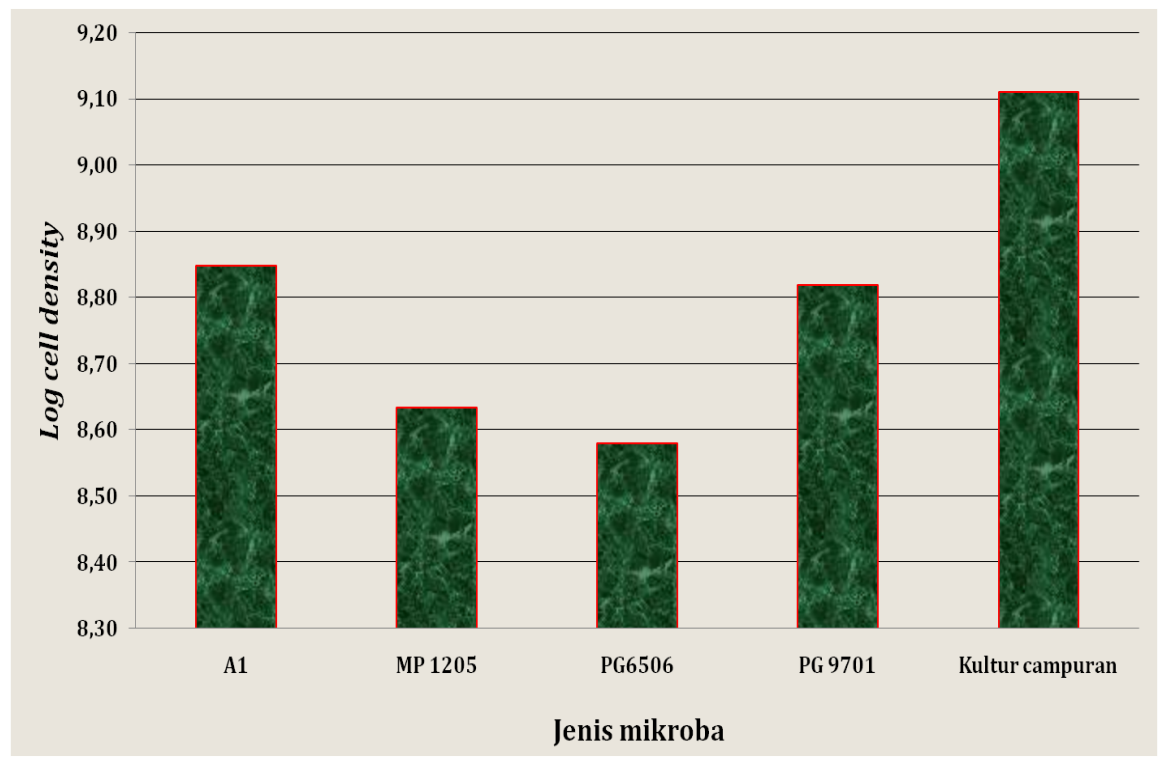

Gambar 2 Jumlah Mikroba Hasil Aktivasi yang digunakan untuk Bioremediasi

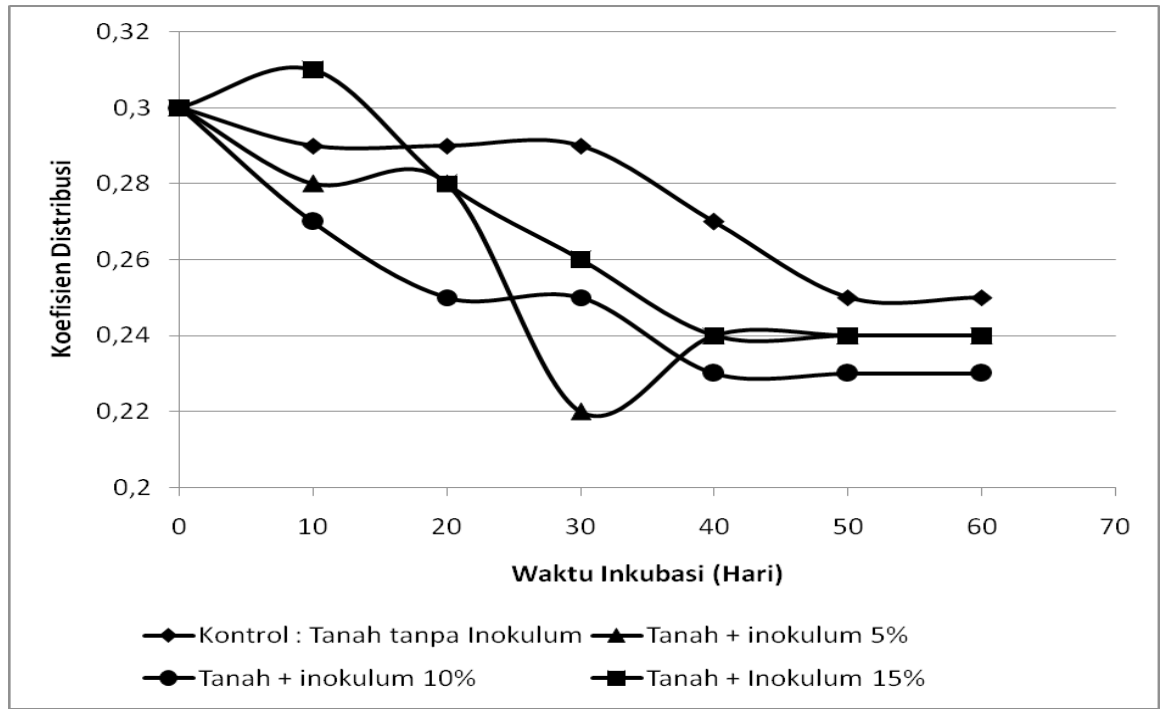

Gambar 3. Koefisien Distribusi Logam $\mathrm{Pb}$ dalam Fase Tertukarkan

bentuk yang berasosiasi dengan karbonat (Bound to carbonates); bentuk yang berasosiasi dengan oksida logam $\mathrm{Fe}$ dan $\mathrm{Mn}$ (Bound to $\mathrm{Fe}-\mathrm{Mn}$ oxides), bentuk yang berasosiasi dengan organik (Bound to organic matter), dan fraksi residu (Residual) (Amanda, 2010).

Pengaruh jumlah inokulum $(5 \% ; 10 \%$ dan $15 \%)$ pada waktu inkubasi terhadap koefisien distribusi logam $\mathrm{Pb}$ dalam fase tertukarkan dapat dilihat pada Gambar 3.Koefisien distribusi untuk fase tertukarkan logam dipengaruhi oleh waktu inkubasi dan jumlah inokulum. Hasil uji ANAVA menunjukkan bahwa perlakuan jumlah inokulum dan waktu inkubasi mempunyai pengaruh yang sangat nyata terhadap respon logam $\mathrm{Pb}$ dalam fase tertukarkan. Namun interaksi antara perlakuan jumlah inokulum dan waktu inkubasi tidak memperlihatkan pengaruh nyata terhadap respon logam $\mathrm{Pb}$ dalam fase tertukarkan.

Hasil uji $\mathrm{F}$ berdasarkan ANAVA untuk perlakuan jumlah inokulum sebesar 13,62 sedangkan nilai $\mathrm{F}$ tabel sebesar 3,42 ( $\alpha$ 99\%). 


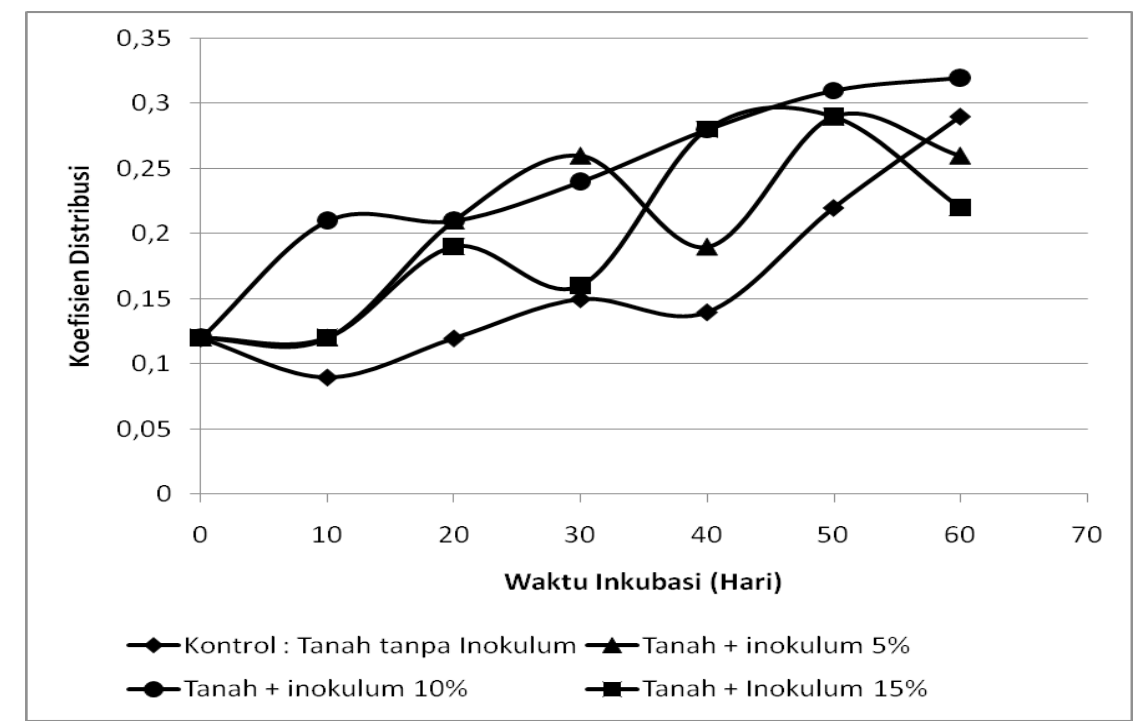

Gambar 4. Koefisien Distribusi Logam Pb dalam Fase Residual

Begitu pula untuk perlakuan waktu inkubasi uji F sebesar 14,708 sedangkan nilai $\mathrm{F}$ tabel sebesar 4,22 ( $\alpha$ 99\%) dan interaksinya memberikan uji $\mathrm{F}$ sebesar 0,874 sedangkan nilai $\mathrm{F}$ tabel sebesar $2,48(\alpha 99 \%)$.

Hasil perhitungan koefisien distribusi dari fraksi tertukarkan logam $\mathrm{Pb}$ pada perlakuan penambahan inokulum $10 \%$ menunjukkan kecenderungan yang baik dibandingkan dengan penambahan inokulum $5 \%$ dan $15 \%$. Kondisi ini ditunjukkan dengan nilai koefisien distribusi yang paling rendah. Bila ditinjau dari perlakuan waktu inkubasi menunjukkan bahwa waktu inkubasi 40 hari memberikan nilai koefisien distribusi cenderung konstan.

Pola yang sama terjadi pada pengamatan terhadap fase residual yang dapat dilihat pada Gambar 4. Hasil uji ANAVA menunjukkan bahwa perlakuan jumlah inokulum dan waktu inkubasi mempunyai pengaruh yang sangat nyata terhadap respon logam $\mathrm{Pb}$ dalam fase residual, sedangkan interaksi antar kedua perlakuan tersebut tidak memberikan pengaruh yang nyata. Hasil uji $\mathrm{F}$ berdasarkan ANAVA untuk perlakuan jumlah inokulum sebesar 21,44 sedangkan nilai $\mathrm{F}$ tabel sebesar 3,42 ( $\alpha$ 99\%). Begitu pula untuk perlakuan waktu inkubasi sebesar 20,71 sedangkan nilai $\mathrm{F}$ tabel sebesar 4,22 ( $\alpha$ 99\%) dan interaksinya adalah sebesar 2,05 sedangkan nilai F tabel sebesar 2,48 ( $\alpha$ 99\%).
Hasil perhitungan koefisien distribusi dari fraksi residual logam $\mathrm{Pb}$ pada perlakuan penambahan inokulum $10 \%$ menunjukkan kecenderungan yang baik dibandingkan dengan penambahan inokulum 5\% dan 15\%. Tanah terkontaminasi logam $\mathrm{Pb}$ dapat dipulihkan dengan proses bioremediasi. Hal ini ditunjukkan dari kemampuan mikroba untuk mengubah logam, terlihat dari kandungan logam $\mathrm{Pb}$ dalam fase tertukarkan semula sebesar 19,36 mg/ $\mathrm{kg}$ berkurang menjadi $15,91 \mathrm{mg} / \mathrm{kg}$ (18\%). Selanjutnya ditinjau dari fase residual terjadi peningkatan kandungan logam $\mathrm{Pb}$ yang semula $7,77 \mathrm{mg} / \mathrm{kg}$ menjadi $17,00 \mathrm{mg} / \mathrm{kg}$ (118\%), hal ini berarti adanya proses bioremediasi mengubah sifat logam yang semula aktif menjadi tidak aktif.

Bila dibandingkan dari penelitian Huang et al. (2005) menunjukkan bahwa dengan penambahan jamur Phanerochaete chrysosporium sebesar 2\% dengan penambahan jerami (rasio 1:6) dalam waktu inkubasi 42 hari dapat mengubah logam $\mathrm{Pb}$ dalam fase tertukarkan semula sebesar 258,9 $\mathrm{mg} / \mathrm{kg}$ berkurang menjadi $12,5 \mathrm{mg} / \mathrm{kg}$ (95\%), dan dalam fase residual dapat meningkatkan kandungan logam $\mathrm{Pb}$ yang semula $8,4 \mathrm{mg} / \mathrm{kg}$ menjadi $129,6 \mathrm{mg} / \mathrm{kg}$ (1443\%). Perbedaan hasil penelitian tersebut disebabkan karena berbedanya jenis mikroorganisme yang digunakan dan adanya perlakuan penambahan jerami sebagai bulking agents. 
Pengamatan terhadap fraksi lainnya, yaitu fase terikat karbonat dan fraksi oksidasi metal (Fe dan $\mathrm{Mn}$ ) nilainya cukup rendah dibandingkan fraksi lain. Kondisi ini menunjukkan bahwa bentuk $\mathrm{Pb}$ ditransfer ke dalam bentuk fraksi lain. Koefisien distribusi logam $\mathrm{Pb}$ dalam fase terikat karbonat dan fraksi oksidasi metal $(\mathrm{Fe}$ dan $\mathrm{Mn}$ ) serta fase terikat organik dapat dilihat pada Gambar 5, 6 dan 7. Secara keseluruhan menunjukkan bahwa mikroba konsorsium yang digunakan dalam percobaan mempunyai potensi untuk meremediasi logam $\mathrm{Pb}$ dalam tanah yang terkontaminasi limbah sludge industri kertas proses deinking. Waktu inkubasi mempengaruhi koefisien distribusi logam $\mathrm{Pb}$, selain itu jumlah inokulum juga berpengaruh. Pengamatan sampai waktu inkubasi 40 hari menunjukkan bahwa koefisien distribusi fraksi tertukarkan logam $\mathrm{Pb}$ menurun, hal ini menunjukkan bahwa salah satu bentuk logam $\mathrm{Pb}$ ditransform ke dalam bentuk fraksi lain hingga terjadi adanya perubahan logam aktif dalam tanah menjadi tidak aktif oleh aktivitas mikroba.

Kondisi optimum diperoleh pada penambahan inokulum $10 \%(\mathrm{v} / \mathrm{w})$ dengan waktu inkubasi 40 hari, yang ditunjukkan oleh menurunnya koefisien distribusi sebesar 21\% ( dari 0,29 turun menjadi 0,23 ) dan meningkatnya koefisien distribusi sebesar $146 \%$ ( dari 0,13 meningkat menjadi $0,32)$. Namun kemampuan remediasi logam $\mathrm{Pb}$ oleh mikroba dalam penelitian ini masih relatif rendah, untuk meningkatkan kemampuan ini perlu penelitian lebih lanjut tentang kemampuan masing-masing isolat dalam mengikat logam berat $\mathrm{Pb}$ sehingga diketahui peran mikroba yang mana yang sangat berperan dalam proses bioremediasi tersebut.

\section{Germination Index}

Germination index (GI) adalah parameter yang sangat sensitive yang digunakan untuk mengevaluasi toksisitas suatu tanaman terhadap bahan tertentu. GI dihitung dengan cara mengombinasikan kecambahan biji relatif dengan perpanjangan akar relatif. Menurut Zucconi et al., 1981 dalam Gao et al., 2010 menyatakan jika Germination index di atas $80 \%$ maka tanah dapat dikatakan bebas dari senyawa yang bersifat toksik bagi tanaman.

Perhitungan germination index dilakukan terhadap tanah yang telah diremediasi pada kondisi remediasi yang optimal, yaitu pada penambahan inokulum 10\%. Hasil Germination index yang diperoleh dibandingkan dengan kontrol tanpa penambahan inokulum. Pengamatan menunjukkan bahwa GI dari semua perlakuan dari hari ke 10-60 menunjukkan nilai GI di atas $80 \%$ artinya tanah yang telah diremediasi tidak lagi mengandung material yang bersifat toksik pada tanaman. Nilai germination index dapat dilihat pada Tabel 2. Nilai GI pada perlakuan penambahan inokulum kecenderungannya semakin meningkat pada kisaran $84,3 \%$ hingga $136,7 \%$ dari waktu inkubasi 10 hari sampai dengan 60 hari, dibandingkan dengan perlakuan kontrol tanpa kecenderungannya cukup berfluktuasi pada kisaran $88,8 \%$ hingga $111,7 \%$ dari waktu inkubasi 10 hari sampai dengan 60 hari. Walaupun pada perlakuan kontrol sudah menunjukkan bahwa tanah sudah kurang toksik, akan tetapi dengan perlakuan penambahan inokulum menunjukkan bahwa tanah lebih tidak lagi mengandung material yang bersifat toksik.

Tabel 2. Germination Index (\%)

\begin{tabular}{ccccccc}
\hline & \multicolumn{7}{c}{ Waktu Inkubasi (Hari) } \\
\cline { 2 - 7 } Perlakuan & 10 & 20 & 30 & 40 & 50 & 60 \\
\hline $\begin{array}{c}\text { Kontrol tanpa penambahan } \\
\text { inokulum } \\
\text { Tanah + 10\% inokulum }\end{array}$ & 88,8 & 104 & 111,7 & 108,4 & 93,1 & 89,5 \\
\hline
\end{tabular}




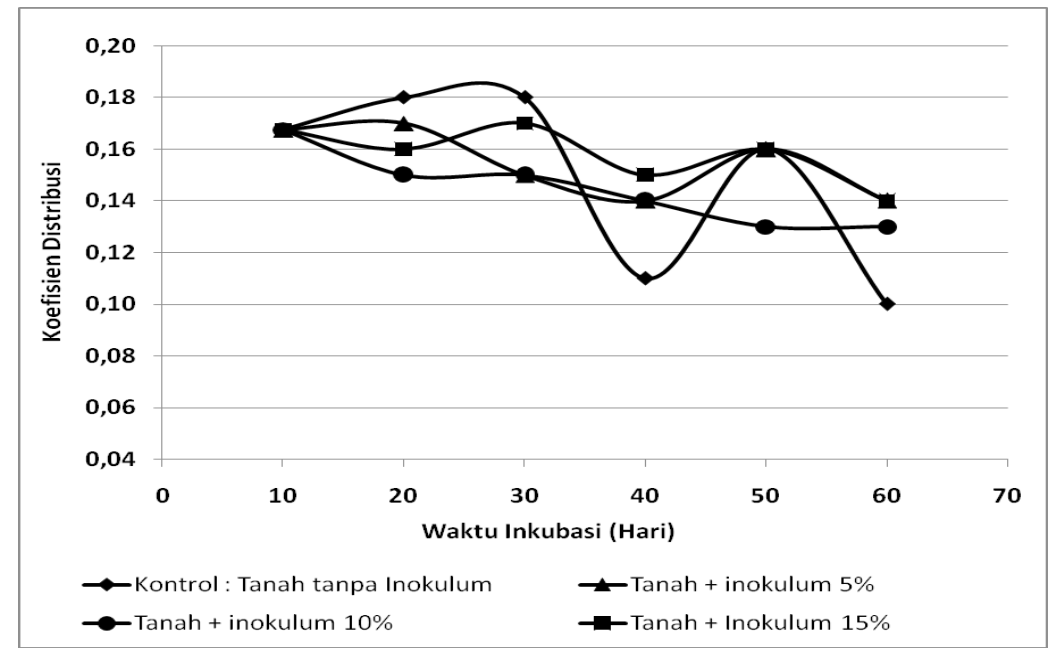

Gambar 5. Koefisien Distribusi Logam Pb dalam Fase Terikat Karbonat

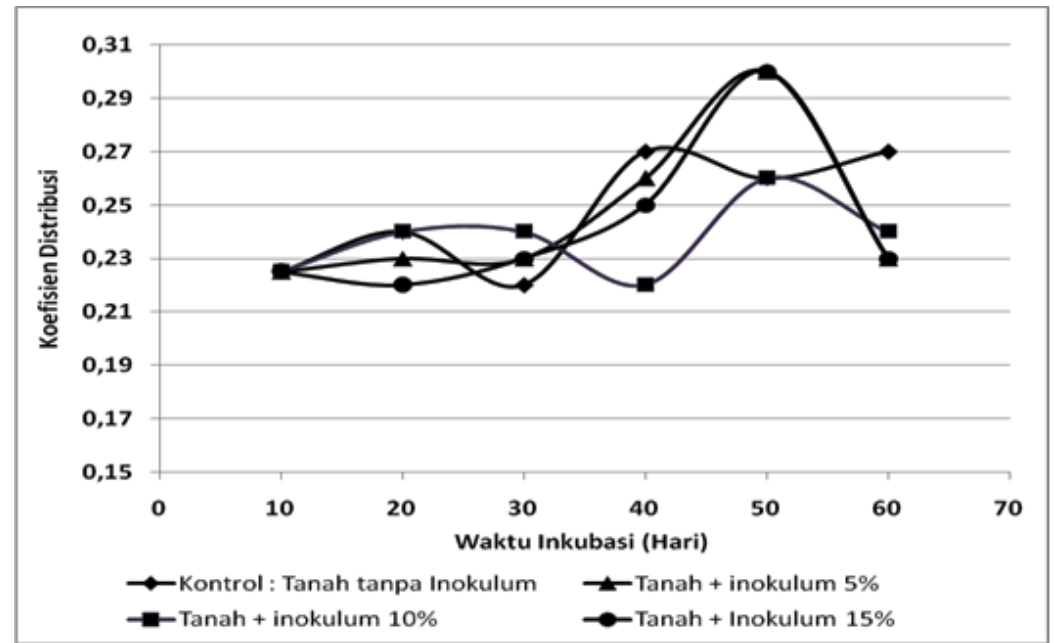

Gambar 6. Koefisien Distribusi Logam Pb dalam Fase Terikat Fe-Mn

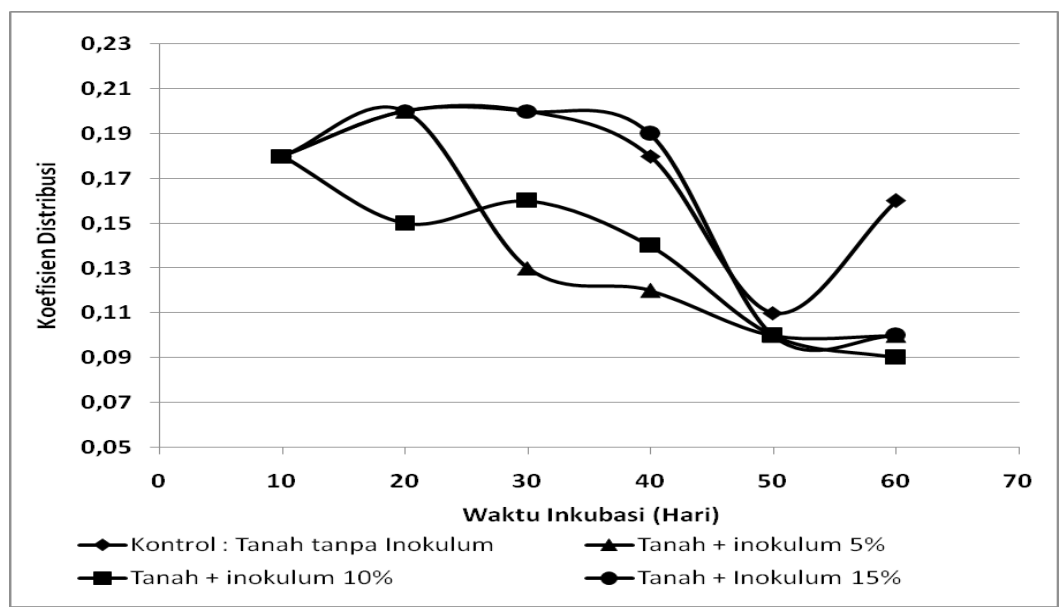

Gambar 7. Koefisien Distribusi Logam Pb dalam Fase Terikat Organik 


\section{KESIMPULAN}

Tanah terkontaminasi logam $\mathrm{Pb}$ dapat dipulihkan dengan proses bioremediasi. Hal ini ditunjukkan dari kemampuan mikroba untuk mengubah logam, terlihat dari penurunan koefisien distribusi fase tertukarkan dan peningkatan fase residual. Kondisi optimum diperoleh pada penambahan inokulum 10\% (v/w) dengan waktu inkubasi 40 hari. Mikroba konsorsium dari campuran PG 65-06 (A) : PG 97-02 (B) : MR 1.12-05 (C) dan A1 (D) dengan perbandingan 1:1:1:1 mempunyai kemampuan untuk meremediasi tanah terkontaminasi logam berat $\mathrm{Pb}$ dari limbah padat industri kertas proses deinking. Keberhasilan proses bioremediasi ditunjukkan dengan adanya penurunan logam $\mathrm{Pb}$ pada fase tertukarkan seiring dengan meningkatnya logam $\mathrm{Pb}$ pada fase residu oleh adanya aktifitas mikroba, artinya mengubah sifat logam yang semula aktif menjadi tidak aktif, terlihat dari kandungan logam $\mathrm{Pb}$ dalam fase tertukarkan semula sebesar $19,36 \mathrm{mg} / \mathrm{kg}$ berkurang menjadi $15,91 \mathrm{mg} / \mathrm{kg}$ dan pada fase residual terjadi peningkatan kandungan logam $\mathrm{Pb}$ yang semula $7,77 \mathrm{mg} / \mathrm{kg}$ menjadi $17,00 \mathrm{mg} /$ $\mathrm{kg}$ atau menurunnya koefisien distribusi sebesar $21 \%$ dalam fase tertukarkan dan meningkatnya koefisien distribusi sebesar $146 \%$ dalam fase residual. Nilai germination index (GI) pada kisaran $84,3-136,7 \%$ berarti tanah yang telah diremediasi tidak lagi mengandung material yang bersifat toksik pada tanaman.

\section{SARAN}

Untuk mengetahui peran mikroba dalam proses bioremediasi maka perlu dilakukan penelitian lebih lanjut tentang kemampuan masing-masing isolat dalam mengikat logam $\mathrm{Pb}$.

\section{UCAPAN TERIMA KASIH}

Kami menyampaikan terima kasih kepada Kementerian Negara Riset dan Teknologi atas program insentifnya dan PT. Adiprima Suraprinta dalam penyediaan tanah terkontaminasi sehingga penelitian ini dapat berlangsung dengan lancar.

\section{DAFTAR PUSTAKA}

Alloway, B.J. 1995. Heavy Metals in Soils. Blackie Academic and Professional, Chapman \& Hall, edisi kedua.

Amanda, J.Z; David. C.W, 2010, Heavy Metal and Trace Metal Analysis in Soil by Sequential Extraction : A Review of Procedures, International Journal of Analytical Chemistry, Hindawi Publishing Corportion

Donlon, D.L. dan Bauder, J.W. A General Essay on Bioremediation of Contaminated Soil, http://waterquality.montana.edu/docs/ methane/Donlan.shtml [6/06/2011]

Erny, Y.; Dwi, N.S; Rasti, S., 2003. Koleksi, Karakterisasi dan Preservasi Mikroba Remediasi, Prosiding Seminar Hasil Penelitian Rintisan dan Bioteknologi Tanaman

Erman, M. 2006. Pemanfaatan Mikroba dalam Bioremediasi suatu Teknologi Alternatif untuk Pelestarian Lingkungan. USU Respository

Gao, M.; Liang, F.; Yu, A.; Li, B.; Yang, L, 2010. Evaluation of stability and maturity during forced-aeration composting of chicken manure and sawdust at different $\mathrm{C} / \mathrm{N}$ ratios, Elsevier.

Gottsching, L; Pakarinen, H, 2000. Recycled Fiber and Deinking, Papermaking Science and Technology, penerbit TAPPI.

Hardiani.H. 2008 "Pemulihan Lahan Terkontaminasi Limbah B3 dari Proses Deinking Industri Kertas Secara Fitoremediasi “, Jurnal Riset Industri. Vol. 2. No.2. Agustus 2008, ISSN. 1978-5852, Hal. $64-75$.

Huang, D. L., Guang M.Z., Xiao, Y.J., Chong, L.F., Hong, Y.Y., Guo, H.H., Hong, L.L., 2005. "Bioremediation of $\mathrm{Pb}$ contaminated soil by incubating with Phanerochaete chrysosporium and straw" College of Environmental Science and Engineering, Hunan University, Changsha 410082, Hunan, China.

Mamik, S. 2004. Pemanfaatan Bakteri Pengakumulasi Logam Berat $\mathrm{Pb}$ dan $\mathrm{Cd}$ untuk Menurunkan Kandungan Logam Berat Pada Beras Tercemar Limbah Industri, Tesis, Sekolah Pascasarjana, Institut Pertanian Bogor. 
Notodarmojo, S. 2005. Pencemaran Tanah dan Air Tanah. Penerbit ITB. ISBN 979-350743-8.

Notohadiprawiro, T., 2006, Logam Berat dalam Pertanian, Ilmu Tanah, Universitas Gajah Mada.

Suhendrayatna. 2001. Bioremoval Logam Berat dengan Menggunakan Mikroorganisme: Suatu Kajian Kepustakaan (Heavy Metal Bioremoval by Microorganisms: A Literature Study) Sinergy Forum - PPI Tokyo Institute of Technology.
Vidali, M. 2001. Bioremediation. An overview. Pure Appl. Chem., Vol. 73, pp. 1163-1172.

Widowati, W.; Sastiono, A.; Jusuf, R. 2008. "Efek Toksik Logam" Pencegahan dan penanggulangan pencemaran. Penerbit ANDI Yogyakarta. 